\title{
Foliar Application of Calcium Chloride to Decrease Ethion Residues in the Oil of Chamomile Flowers and Soybean Seeds
}

\author{
H. Abdel-Gawad ${ }^{\#}$, H. A. Kamel" and B. Hegazi \\ Applied Organic Chemistry Dept., NRC and *Radioisotopes \\ Department, Atomic Energy Authority, Cairo, Egypt.
}

\begin{abstract}
7 HE EFFECTIVENESS of the foliar application of different concentrations of calcium chloride solution $(0.5,1$ and $1.5 \%)$ to reduce ethion residues in chamomile flowers and soybean seeds was studied. The ethion insecticide and some of its degradation products have been prepared for the present investigation. The concentration of ${ }^{14} \mathrm{C}$-ethion activity was decreased by increasing the concentration of $\mathrm{CaCl}_{2}$ solution. The percentage of removal due to calcium chloride application increased from $33 \%$ to $36 \%$ and from $9 \%$ to $23 \%$ for both chamomile flowers and soybean seeds after 30 days of the last application. The concentration of ${ }^{14} \mathrm{C}$ - ethion on chamomile and soybean oils at 30 days after the last application was 0.36 and $0.43 \mathrm{ppm}$, respectively at $1.5 \% \mathrm{CaCl}_{2}$. Chromatographic analysis of oil extracts of both plants revealed the presence of ethion monooxon, ethion dioxon, $O, O$-diethyl phosphorothioate, $O$-ethyl phosphorothioate, in addition to the parent compound. All concentrations of $\mathrm{CaCl}_{2}$ used caused insignificant changes in the leaves soluble protein of the two examined plants relative to the control and ethion treated plants. Soluble sugars of soybean leaves were significantly changed by ethion and $\mathrm{CaCl}_{2}$ treatment when compared with control.
\end{abstract}

Keywords: Ethion residues, Chamomile flowers, soybean seeds and Calcium chloride.

Soybean and chamomile plants are considered to be important economic crops in Egypt. Chamomile (Matricaria chamomilla L.) is a medicinal plant species from the Asteraceae family ${ }^{(1)}$. Nowadays, chamomile is a highly favored and muchused medicinal plant in folk and traditional medicine throughout the world ${ }^{(2)}$, and can therefore be considered as an important medicinal species ${ }^{(3)}$. Its oil is commonly known as natural ingredient for cosmetics and pharmaceuticals ${ }^{(4,5)}$. While soybean [Glycine max (L.) Merr.] has been known to far-eastern countries as one of the most economic and nutritious food for centuries. Given the various nutraceutical applications of soybean in reducing the risk of major killer diseases such as breast cancer, cardiovascular disease, osteoporosis, diabetes, and its role in people in western countries are also seeking to incorporate soy-foods into their regular diet ${ }^{(6)}$. Soybean oil accounts for over $75 \%$ of the total vegetable oil in human foods ${ }^{(7)}$.

\#Corresponding author: E-mail: abdelgawadhassan@ hotmail.com 
The organophosphorus pesticides most commonly used in the cultivation of essential and fixed oil plants travel through the vascular system of the plant and are absorbed at the cellular level ${ }^{(8)}$. Ethion $\left(O, O, O^{\prime}, O^{\prime}\right.$-tetraethyl $S, S^{\prime}$-methylene diphosphorodithioate, is used on plants and animals as an insecticide, acaricide and ovicide ${ }^{(9)}$

Calcium chloride $\left(\mathrm{CaCl}_{2}\right)$ has many functions in today's world. Chemically, it is a common salt known for its desiccant or drying quality ${ }^{(10)}$. Calcium chloride is used as a nutrient for plants ${ }^{(11)}$ and pesticide residue removal in plants ${ }^{(12)}$.

Many researchers have proposed some methods to reduce pesticide residues from fruit ${ }^{(13)}$, vegetables ${ }^{(14,15)}$, from water ${ }^{(16,17)}$ and soils ${ }^{(18,19)}$.

The objectives of the present study were (i) to determine ethion residues in chamomile flowers and soybean seeds after foliar application of calcium chloride (ii) to determine and identify ethion residues in chamomile and soybean oils after foliar application of calcium chloride and (iii) to deduce physiological properties of chamomile and soybean plants after foliar application of calcium chloride.

\section{Materials and Methods}

\section{Chemicals}

${ }^{14} \mathrm{C}$-ethion labeled at carbon atom of ethyl groups (I) was prepared in one vesseled reaction using ${ }^{14} \mathrm{C}$-ethanol (Sp. Act. $37 \mathrm{MBq}$, Amersham, England) according to Abdel-Gawad et al. ${ }^{(12)} \cdot{ }^{14} \mathrm{C}$-Ethion had specific activity $(7.4 \mathrm{MBq} / \mathrm{g})$, the radiometric purity was greater than $98 \%$ (Fig. 1).

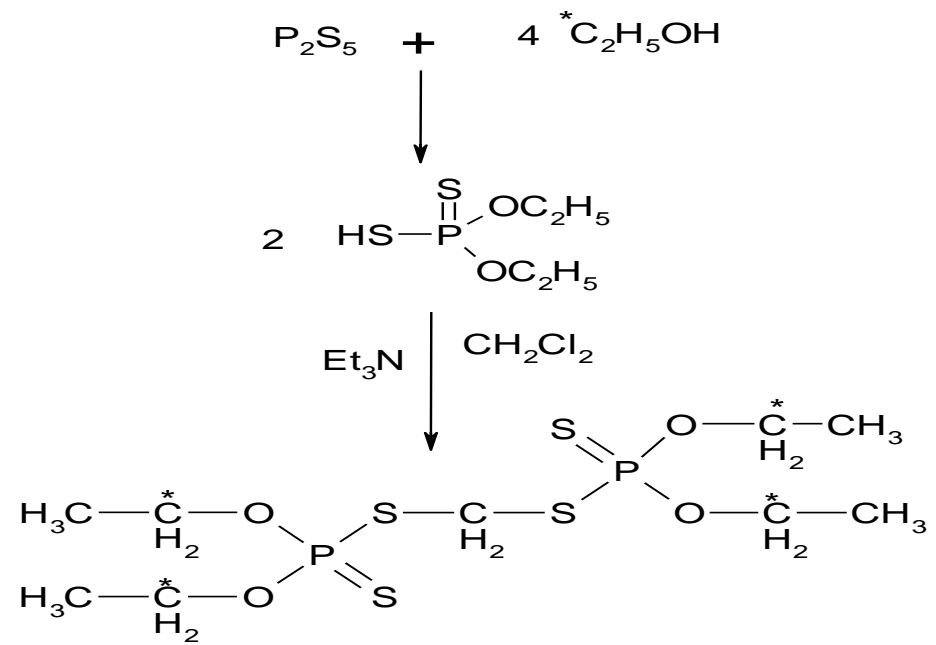

\section{( I )}

Fig. 1. Pathway of ${ }^{14} \mathrm{C}$-ethion synthesis. 
The non-labeled insecticide and some of its degradation products have been prepared in our laboratory ${ }^{(12)}$ for identification purposes such as Ethion monooxon (II), Ethion dioxon (III), $O, O$-diethyl phosphorothioate (IV) and $O$ ethyl phosphorothioate $(\mathrm{V})$. The structures of these compounds were shown in Fig. 2.<smiles>CCOP(=O)(OCC)SCSP(=S)(OCC)OCC</smiles><smiles>CCOP(=O)(OCC)SCSP(=O)(OCC)OCC</smiles><smiles>CCOP(O)(=S)OCC</smiles>

(IV)<smiles>CCOP(O)(O)=S</smiles>

(V)

Fig. 2. Main degradation products of ethion insecticide.

\section{Plant material and experimental design}

Chamomile plantlets and Soybean seeds (var. Crawford) were purchased from Agriculture Research Center, Giza, Egypt.

\section{Cultivation}

Cultivation was carried out during 2010 in the experimental net house of the Radioisotopes Department, Nuclear Research Center, Atomic Energy Authority, Egypt, in clay soil with the following characteristics: $\mathrm{pH}=7.7, \mathrm{Ec}(\mathrm{Mmose} / \mathrm{cm})$ $=1.05$, Saturation point $=50 \%, \mathrm{CO}_{3}=0 \mathrm{M}$ eq. $\left.\mathrm{l}^{-1}\right), \mathrm{HCO} 3=2\left(\mathrm{M}\right.$ eq. $\left.\mathrm{l}^{-1}\right), \mathrm{Cl}=$ 3.0 M eq. $^{-1}$ ), SO4 $=5.7 \mathrm{M}$ eq. $\left.\mathrm{l}^{-1}\right), \mathrm{Ca}=2.1 \mathrm{M}$ eq. $\left.\mathrm{l}^{-1}\right), \mathrm{Mg}=0.9 \mathrm{M}$ eq. $\left.\mathrm{l}^{-1}\right), \mathrm{Na}$ $=7.5 \mathrm{M}$ eq..$^{-1}$ ) and $\mathrm{K}=0.2 \mathrm{M}$ eq. $\mathrm{l}^{-1}$ ). Chamomile was cultivated from January to April while, soybean was cultivated from May to September. The experimental design was a completely randomized block with three replicates. 
The irrigation and fertilization of the both plants were performed according to instruction of Ministry of Agriculture, Egypt.

\section{Treatment}

Both $\mathrm{CaCl}_{2}$ and ethion pesticide were applied on the plant leaves at the early time of blooming. Four concentrations $(0,0.5,1.0$ and $1.5 \%, 2 \mathrm{ml} / \mathrm{plant})$ of $\mathrm{CaCl}_{2} \cdot 2 \mathrm{H}_{2} \mathrm{O}$ (Fluka) were applied four times, one week before and after each application of the ethion pesticide. Ethion was applied at concentrations ( 0 and 4 $\mathrm{mg} /$ plant) twice 15 and 21 days apart in chamomile and soybean, respectively. For studying the fate and pesticide residue ${ }^{14} \mathrm{C}$-ethion was used while, non labeled form was used with plants used for soluble sugars and protein measurements.

A combination between $\mathrm{CaCl}_{2}$ and ethion was carried out to give the following eight treatments : 1) $0 \% \mathrm{CaCl}_{2}+0 \%$ ethion (control); 2) $0 \% \mathrm{CaCl}_{2}+4$ mg ethion; 3) $0.5 \% \mathrm{CaCl}_{2}+0 \%$ ethion, 4) $1.0 \% \mathrm{CaCl}_{2}+0 \%$ ethion; 5) $1.5 \%$ $\mathrm{CaCl}_{2}+0 \%$ ethion; 6) $0.5 \% \mathrm{CaCl}_{2}+4 \mathrm{mg}$ ethion, 7) $1.0 \% \mathrm{CaCl}_{2}+4 \mathrm{mg}$ ethion and 8) $1.5 \% \mathrm{CaCl}_{2}+4 \mathrm{mg}$ ethion.

Chamomile flowers and soybean pods were collected after 30 days following the second spray of labeled ethion with different concentration of foliar application of $\mathrm{CaCl}_{2}$. The radioactive residues of chamomile flowers and soybean seeds were determined by digestion followed by liquid scintillation counting (LSC).

\section{Extraction of oil from chamomile flowers and soybean seeds}

Chamomile and soybean oils were extracted from dried flowers and seeds by using a Soxhlet apparatus for $12 \mathrm{hr}$ with $\mathrm{n}$-hexane. After evaporation of hexane under reduced pressure, radioactivity in the chamomile and soybean oil was measured.

\section{Isolation and characterization of ${ }^{14} \mathrm{C}$-residues}

Analysis of radioactive compounds was achieved by thin layer chromatography (TLC). Samples of chamomile and soybean oils after one month of the second application were partitioned between acetonitrile and hexane three times; the radioactive residues were distributed between the two layers. Analysis of oil extracts were achieved by thin layer chromatography (TLC) on silica gel plates [Merck-silica gel $60 \mathrm{~F}_{254]}$. The solvent systems used were.
System 1: Toluene: Xylene 20: 20
$(\mathrm{v} / \mathrm{v})$
System 2: Dioxane: Xylene : Petrolum ether 10:20: $20 \quad$ (v/v/v)
System 3: n-Hexane: Ethyl acetate 98:2 (v/v)

Authentic samples were run alongside as references and spots were made visible by exposing the plates to UV- source. After preliminary spray with $\mathrm{PdCl}_{2}$ solution the plates were subjected to $\mathrm{I}_{2}$ vapour to detect the compound by color.

Egypt. J. Chem. 54, No. 2 (2011) 


\section{Pesticide residues analysis}

The pesticide concentration was determined by radio assay method as follows: The radioactivity in oil extracts was measured directly by liquid scintillation counting (LSC) (Packard Model TRI-CARB 2300 TR) in vials using a dioxanebased scintillation cocktail composed of dioxane $(1 \mathrm{~L})$, naphthalene $(100 \mathrm{~g})$,[PPO; 2,5-diphenyloxazole] (10 g) and POPOP; 1,4-di[2-(5-phenyloxazolyl)] -benzene $(0.25 \mathrm{~g})$. Radioactivity in flowers and seeds $(100 \mathrm{mg})$ was determined by digestion using $\mathrm{H}_{2} \mathrm{O}_{2}$ and Solusol followed by liquid scintillation counting. Silica gel plates were separately scrapped (1 cm zones) and silica gel was eluted with methanol followed by LSC. The counts were corrected for background and quench effect by channel ratio method.

\section{Measurement of soluble sugar}

The pool of soluble sugars was extracted from oven dried leaves $\left(80{ }^{\circ} \mathrm{C}\right)$ using $80 \%$ hot ethanol and the total concentration was determined by the modified method of phenol/sulphuric acid assay for total carbohydrates ${ }^{(20)}$.

\section{Measurement of protein}

The protein pool was extracted with phosphate buffer $\mathrm{pH} 8.04$ and quantitatively determined using Comassie brilliant blue G 250 according to the method of Bradford ${ }^{(21)}$.

\section{Statistical analysis}

The data of soluble carbohydrates and protein were subjected to One-way ANOVA and the differences between means were at the 5\% probability level using Duncan's new multiple range tests. The software SPSS, version 10 (SPSS, Richmond, USA) was used as described by Dytham ${ }^{(22)}$.

\section{Results and Discussion}

\section{Pesticide residues}

Effect of foliar applications of $\mathrm{CaCl}_{2}$ on pesticide residues in chamomile flowers and soybean seeds

Table 1 shows the amount of ${ }^{14} \mathrm{C}$-ethion residues from chamomile flowers and soybean seeds at different foliar applications of calcium chloride concentrations after 30 days of the last application. The concentration of ${ }^{14} \mathrm{C}$ ethion decreased by increasing the concentration of $\mathrm{CaCl}_{2}$ solution. At $0.5 \%$ $\mathrm{CaCl}_{2}$, the removal of ethion residues was $33 \%$, whereas at $1 \%$ and $1.5 \% \mathrm{CaCl}_{2}$ applications, the removal of ${ }^{14} \mathrm{C}$-ethion residues showed the same trend. The percent removal due to foliar applications of $\mathrm{CaCl}_{2}$ after 30 days of the last application increased from $34 \%$ to $36 \%$. Distribution and elimination of ${ }^{14} \mathrm{C}$-ethion 
insecticide in chamomile flowers and oil was investigated ${ }^{(12)}$. Ethion residues were decreased by sun drying of chamomile flowers. The percentage of removal was $18-47 \%{ }^{(12)}$. In soybean seeds, the percent removal due to foliar applications of $\mathrm{CaCl}_{2}$ after 30 days of the last application increased from $9 \%$ to $23 \%$. Malakouti and Afkhami ${ }^{(23)}$ showed that the residues of the pesticides (Diazinon and Phosalon) were significantly reduced after foliar calcium applications. Diazinon concentration was reduced from $4 \mathrm{ppm}$ to $3 \mathrm{ppm}$, and Phosalon concentration was decreased from $1.24 \mathrm{ppm}$ to $1.10 \mathrm{ppm}$ due to calcium application.

TABLE 1. Effect of foliar applications of calcium chloride on the distribution of ${ }^{14} \mathrm{C}$ ethion residues (ppm) in chamomile flowers and soybean seeds after 30 days from the last application.

\begin{tabular}{|c|c|c|c|c|}
\hline Treatment & \multicolumn{4}{|c|}{${ }^{14} \mathrm{C}$-Residues } \\
\hline \multirow{2}{*}{$\begin{array}{c}\mathbf{C a C l}_{2} \\
\text { concentrations }\end{array}$} & \multicolumn{2}{|c|}{ chamomile flowers } & \multicolumn{2}{|c|}{ soybean seeds } \\
\hline & ppm* & Reduction, \%** & ppm* & Reduction, $\% * *$ \\
\hline $0.0 \%$ & $\begin{array}{c}2.42 \\
\pm 0.04\end{array}$ & 0 & $\begin{array}{c}1.93 \\
\pm 0.28\end{array}$ & 0 \\
\hline $0.5 \%$ & $\begin{array}{c}1.62 \\
\pm 0.11\end{array}$ & 33 & $\begin{array}{c}1.75 \\
\pm 0.03 \\
\end{array}$ & 9 \\
\hline $1.0 \%$ & $\begin{array}{c}1.59 \\
\pm 0.17\end{array}$ & 34 & $\begin{array}{c}1.53 \\
\pm 0.05\end{array}$ & 21 \\
\hline $1.5 \%$ & $\begin{array}{c}1.55 \\
\pm 0.09\end{array}$ & 36 & $\begin{array}{c}1.48 \\
\pm 0.01\end{array}$ & 23 \\
\hline
\end{tabular}

*: Results are expressed as mean \pm SD for three determinations for each sample.

$* *$ Reduction $=\left[\right.$ (pesticide conc. - different concentration of $\left.\mathrm{CaCl}_{2}\right) /$ pesticide conc. $] \times 100$.

Distribution of radioactive ${ }^{14} \mathrm{C}$-ethion residue in chamomile and soybean oils

The ${ }^{14} \mathrm{C}$-residues in chamomile and soybean oils after application of ${ }^{14} \mathrm{C}$ ethion at different concentrations of calcium chloride were determined as shown in Table 2. The concentration of ${ }^{14} \mathrm{C}$ - ethion on chamomile oil at 30 days after the last application of the pesticide and $\mathrm{CaCl}_{2}$ were $0.57,0.37$ and $0.36 \mathrm{ppm}$ at $0.5,1$ and $1.5 \% \mathrm{CaCl}_{2}$ solution, respectively. The percentage of removal due to application of $\mathrm{CaCl}_{2}$ increased by increasing the concentration of $\mathrm{CaCl}_{2}$ solution and reached the maximum value of removal $(42 \%)$ at $1.5 \% \mathrm{CaCl}_{2}$. The distribution of radioactive ${ }^{14} \mathrm{C}$-ethion in soybean oil after 30 days from the last application of ${ }^{14} \mathrm{C}$-ethion in oil at different concentrations of calcium chloride was detected. The percentage of removal due to application of $\mathrm{CaCl}_{2}$ increased by increasing the concentration of $\mathrm{CaCl}_{2}$ solution and reached the maximum value of removal (14\%) at $1.5 \% \mathrm{CaCl}_{2}$. Abdel-Gawad et al., ${ }^{(12)}$ found that chamomile flowers obtained from ${ }^{14} \mathrm{C}$-ethion treated plants contained $\left(6.3 \times 10^{-7} \%\right)$ of the applied dose. The insecticide residues in crude oil, methanol and cake amounted to $26 \%, 15 \%$ and $54 \%$, respectively of original residues inside the flowers.

Egypt. J. Chem. 54, No. 2 (2011) 
Foliar Application of Calcium Chloride 
Identification and characterization of metabolites in chamomile and soybean oil

Table 3 shows the $R_{f}$ values and the average concentration of ${ }^{14} \mathrm{C}$-ethion residues in chamomile and soybean oils after 30 days from the last application. Ethion and its degradation products were identified in oil extracts at 30 days of the last application of ${ }^{14} \mathrm{C}$-ethion at different concentration of $\mathrm{CaCl}_{2}(0.5,1$ and $1.5 \%$ ), the results showed that ethion concentration decreased by $\mathrm{CaCl}_{2}$ application and reached to 0.05 and $0.04 \mathrm{ppm}$, respectively for chamomile and soybean oils after 30 days at $1.5 \% \mathrm{CaCl}_{2}$. Ethion dioxon and ethion monooxon show the same trend. While $O, O$-diethyl phosphorothioate (IV) and $O$-ethyl phosphorothioate $(\mathrm{V})$ increased during the experimental period. Our results demonstrated that ethion was metabolized to ethion monooxon, ethion dioxon by oxidation and to $O, O$-diethyl phosphorothioate, $O$-ethyl phosphorothioate by hydrolysis in both plants. Distribution and elimination of ${ }^{14} \mathrm{C}$-ethion insecticide in chamomile flowers and oil was studied by Abdel-Gawad et al. ${ }^{(12)}$ they found that the major degradation products were ethion monooxon, ethion dioxon, $O, O$ diethyl phosphorothioate and $O$-ethyl phosphorothioate. Singh et al., ${ }^{(24)}$ studied the persistence of ethion residues on cucumber using gas chromatography with nitrogen phosphorus detector. They found that the average initial deposits of ethion on cucumber fruits were found to be $2.40 \mathrm{ppm}$ and residues of ethion dissipated below the maximum residue limit (MRL) of $0.5 \mathrm{ppm}$ in 7 days. MacNeil and Hikichi ${ }^{(25)}$ studied residues of ethion on pear fruits following its application for the control of pear psylla. They found that ethion residues remained within its MRL. Residues of ethion were estimated in onion after in furrow treatment. It was observed that ethion residues exceeded their MRL value of $0.1 \mathrm{ppm}$ in all the treatments when analyzed 86 days after its treatment at harvest time ${ }^{(26)}$. Arora et al., ${ }^{(27)}$ also, estimated the residues of ethion on pear fruits and these residues were less than the MRL value of $2.0 \mathrm{ppm}$ of ethion on pear fruits. Ethion was applied on brinjal and its residues dissipated below its MRL value of $1.0 \mathrm{ppm}$ after 4 days of its application at recommended dosage ${ }^{(28)}$. Therefore, the results of the present study indicate that the residues of ethion were $0.05 \mathrm{ppm}$ and $0.04 \mathrm{ppm}$ in the oil of both plants. A waiting period of 30 days should be observed before consumption of chamomile and soybean oils as it will be safe for the consumer's health.

Effect of foliar application of $\mathrm{CaCl}_{2}$ on total protein and soluble carbohydrates of the leaves of chamomile and soybean plants

Protein content of the chamomile leaves significantly increased due to ethion treatment relative to control and due to $\mathrm{CaCl}_{2}$ either alone or with ethion. In soybean there was no significant change in the protein due to various treatments (Table 4). Soluble carbohydrates was significantly reduced in chamomile leaves due to pesticide treatment, $1.5 \% \mathrm{CaCl}_{2}$ and pesticide* $0.5 \% \mathrm{CaCl}_{2}$. Although a significant reduction in soluble carbohydrates of soybean due to pesticide, $\mathrm{CaCl}_{2}$ and pesticide with 0.5 and $1 \% \mathrm{CaCl}_{2}$ relative to control there was significant change between the mentioned treatments. These results show that the reduction observed in ethion residues in chamomile flowers oil and soybean oil was not dependent on either protein or soluble carbohydrates contents in the leaves.

Egypt. J. Chem. 54, No. 2 (2011) 
Foliar Application of Calcium Chloride 
TABLE 4. Effect of foliar application of $\mathrm{CaCl}_{2}(0.5,1.0 \& 1.5 \%, 2 \mathrm{ml} / \mathrm{plant}) \mathrm{and} / \mathrm{or}$ ethion insecticide ( $4 \mathrm{mg} / \mathrm{plant})$ on total protein $(\mathrm{mg} / \mathrm{g}$ dry wt.) and soluble carbohydrates $(\mathrm{mg} / \mathrm{g}$ dry $\mathrm{wt}$.) of the leaves of chamomile and soybean plants.

\begin{tabular}{|c|c|c|c|c|c|}
\hline \multirow{2}{*}{ Treatment } & \multicolumn{2}{c|}{$\begin{array}{c}\text { Protein } \\
\text { (mg/g dry wt.) }\end{array}$} & \multicolumn{2}{c|}{$\begin{array}{c}\text { Soluble carbohydrate } \\
\text { (mg/g dry wt.) }\end{array}$} \\
\cline { 2 - 6 } \multicolumn{2}{|c|}{} & Chamomile & Soybean & Chamomile & Soybean \\
\hline \multicolumn{2}{|c|}{ Control } & $14.2 \pm 2.2^{\mathrm{bc}}$ & $12.7 \pm 0.5^{\mathrm{a}}$ & $34.9 \pm 1.5^{\mathrm{a}}$ & $17.7 \pm 2.03^{\mathrm{b}}$ \\
\hline \multicolumn{2}{|c|}{ Pesticide } & $24.0 \pm 2.0^{\mathrm{a}}$ & $11.4 \pm 0.7^{\mathrm{a}}$ & $23.3 \pm 4.2^{\mathrm{c}}$ & $10.3 \pm 0.33^{\mathrm{c}}$ \\
\hline \multirow{3}{*}{$\mathrm{CaCl}_{2}$} & $0.5 \%$ & $15.5 \pm 0.9^{\mathrm{bc}}$ & $12.2 \pm 1.4^{\mathrm{a}}$ & $32.9 \pm 2.5^{\mathrm{ab}}$ & $09.7 \pm 0.66^{\mathrm{c}}$ \\
\cline { 2 - 6 } & $1.0 \%$ & $18.6 \pm 1.3^{\mathrm{b}}$ & $10.2 \pm 0.2^{\mathrm{a}}$ & $35.5 \pm 1.2^{\mathrm{a}}$ & $09.7 \pm 0.88^{\mathrm{c}}$ \\
\cline { 2 - 6 } & $1.5 \%$ & $12.5 \pm 0.5^{\mathrm{c}}$ & $10.5 \pm 0.3^{\mathrm{a}}$ & $13.9 \pm 0.9^{\mathrm{d}}$ & $09.7 \pm 0.67^{\mathrm{c}}$ \\
\hline \multirow{3}{*}{\begin{tabular}{c}
$\mathrm{Pesticide}^{*} \mathrm{CaCl}_{2}$ \\
\cline { 2 - 6 }
\end{tabular}} & $0.5 \%$ & $18.7 \pm 1.7^{\mathrm{b}}$ & $10.4 \pm 0.7^{\mathrm{a}}$ & $24.1 \pm 2.6^{\mathrm{c}}$ & $13.0 \pm 1.73^{\mathrm{c}}$ \\
\cline { 2 - 6 } & $1.0 \%$ & $16.8 \pm 1.8^{\mathrm{bc}}$ & $10.2 \pm 0.4^{\mathrm{a}}$ & $26.8 \pm 1.2^{\mathrm{bc}}$ & $13.3 \pm 0.88^{\mathrm{c}}$ \\
\cline { 2 - 6 } & $1.5 \%$ & $07.5 \pm 1.1^{\mathrm{d}}$ & $10.7 \pm 1.8^{\mathrm{a}}$ & $33.6 \pm 2.8^{\mathrm{ab}}$ & $26.0 \pm 0.58^{\mathrm{a}}$ \\
\hline
\end{tabular}

Data are mean of three replicates, \pm standard error.

Means having the same letter in the same row are not significantly different at $5 \%$.

*Combined treatment (pesticide and $\mathrm{CaCl}_{2}$ ).

\section{Conclusion}

In conclusion the results demonstrate that the levels of pesticide residues in chamomile flowers, soybean seeds and their oils are lowered under the influence of $\mathrm{CaCl}_{2}$. The concentration of ${ }^{14} \mathrm{C}$-ethion activity was decreased by increasing the concentration of $\mathrm{CaCl}_{2}$ solution .The degradation products in chamomile and soybean oils were identified as ethion monooxon, ethion dioxon, $O$-ethyl phosphorothioate, $O, O$-diethyl phosphorothioate, in addition to the parent compound. The reduction observed in ethion residues in chamomile and soybean oils was not dependent on either protein or soluble carbohydrates contents in the leaves. These results show the importance of calcium chloride application in improving the quality of chamomile and soybean plants as well as reducing pesticide residues, which is very important for human safety.

\section{References}

1. Hadj Seyed Hadi, M., Noormohammadi, G., Masoud Sinaki, J., Khodabandeh, N., Yasa, N. and Darzi, M.T., Effects of planting time and plant density on flower yield and active substance of chamomile (Matricaria chamomilla L.), $4^{\text {th }}$ International Crop Science Congress, Brisbane, Australia (2004).

2. Grejtovsky, A., Markusova, K. and Eliasova, A., The response of chamomile (Matricaria chamomilla L.) plants to soil zinc supply. Plant Soil Environ. 52, 1-7 (2006).

Egypt. J. Chem. 54, No. 2 (2011) 
3. Salamon, I., Effect of the internal and external factors on yield and qualitative quantitative characteristics of chamomile essential oil. In: Proceedings of the First International Symposium on Chamomile Research, Development and Production, Presov, Slovakia, pp. 45-64 (2007).

4. Mann, C. and Staba, E.J., The chemistry, pharmacology, and commercial formulations of chamomile. In: Craker, L.E., Simon, J.E. (Ed.), Herbs, Spices, and Medicinal Plants, Recent Advances in Botany, Horticulture and Pharmacology. Haworth Press, Inc., USA, pp. 235-280(2002).

5. Adams, M., Berset, C., Kessler, M. and Hamburger, M., Medicinal herbs for the treatment of rheumatic disorders- A survey of European herbals from the ${ }^{16}$ th and ${ }^{17}$ th century. Journal of Ethno pharmacology, 121(3), 343-359 (2009).

6. Kumar, V., Rani, A., Solanki, S. and Hussain, S.M., Influence of growing environment on the biochemical composition and physical characteristics of soybean seed. Journal of Food Composition and Analysis, 19, 188-95(2006).

7. Conacher, H.B.S. and Mes, J., Assessment of human exposure to chemical contaminants in foods assessment of human exposure to chemical contaminants in foods. Food Addit. Contam. 10, 5- 15(1993).

8. Di Bella, G., Saitta, M., La Pera, L., Alfa, M. and Dugo, G., Pesticide \& plasticizer residues in bergamot oils from Calabria (Italy), Chemosphere, 56, 777-782 (2004).

9. Xia, H. and Ma, X., Phytoremediation of ethion by water hyacinth (Eichhornia crassipes) from water. Bioresource Technology, 97, 1050-1054(2006).

10. Berger, R.L., Kung, J. H. and Young, J.F., Influence of calcium chloride on the drying shrinkage of alite paste. ASTM Journal of Testing and Evaluation 4 (1), 85-93 (1976).

11. Berger, T. W., Eagar, C., Likens, G.E. and Stingeder, G. Effects of calcium and aluminum chloride additions on foliar and through fall chemistry in sugar maples. Forest Ecology and Management, 149 (1-3), 75-90 (2001).

12. Abdel - Gawad, H., Abdelhameed, R.M., Elmesalamy, A.M. and Hegazi, B. Distribution and elimination of ${ }^{14} \mathrm{C}$-ethion insecticide in chamomile flowers and oil. Phosphorus, Sulfur, and Silicon and the Related Elements, 186 (10), 2122-2134 (2011).

13. Sáenz, B.C., Sanz, A.J., Plaza, M.M., Pérez, C.M. and Galbán, B. J., Evaluation of the decay of malathion, dichlofluanid and fenitrothion pesticides in apple samples, using gas chromatography. Food Chemistry, 52, 305-309(1995).

14. Soliman, K.M., Changes in concentration of pesticide residues in potatoes during washing and home preparation. Food and Chemical Toxicology, 39, 887-891(2001).

15. Abou-Arab, A.K., Behavior of pesticides in tomatoes during commercial and home preparation. Food Chemistry, 65, 509-514 (1999). 
16. Zhang, Z, Liu, X. and Hong, X., Effects of home preparation on pesticide residues in cabbage. Food Control, 18, 1484-1487(2007).

17. Ormad, M.P., Miguel, N., Claver, A., Matesanz, J.M. and Ovelleiro, J.L., Pesticides removal in the process of drinking water production. Chemosphere, 71, 97-106 (2008).

18. Manojlovic, D., Ostojic, D.R., Obradovic, B.M., Kuraica, M.M., Krsmanovic, V.D. and Puric, J., Removal of phenol and chlorophenols from water by new ozone generator. Desalination 213, 116-122 (2007).

19. Pierpoint, A.C., Hapeman, C.J. and Torrents, A., Ozone treatment of soil contaminated with aniline and trifluralin. Chemosphere, 50, 1025-1034 (2003).

20. Bradford, M.M., A refined and sensitive method for the quantitative of microgram quantities of protein utilizing the principle of protein-dye binding. Anal.Biochem. 72, 248-254 (1976).

21. Dytham, C., Choosing and Using Statistics: A Biologist's Guide. Blackwell Science Ltd., London, UK. pp. 147 (1999).

22. Taylor, K.A.C.C., A modification of the phenol/sulphuric acid assay for total carbohydrates giving more comparable absorbencies, App. Biochem. \& Biotech. 54, 207-214 (1995).

23. Malakouti, M.J. and Afkhami, M., Foliar application of calcium chloride for improving apple quality and reducing residual pesticides. Acta Hort. (ISHS), 564, 349-353 (2001).

24. Singh, G., Singh, B., battu, R.S., Jyot, G., Singh, B. and Joia, B.S., persistence of ethion residues on cucumber, cucumis sativus (linn.) using gas chromatography with nitrogen phosphorus detector. Bull. Environ. Contam. Toxicol. 79,437-439 (2007).

25. MacNeil, J.D. and Hikichi, M., Degradation of endosulfan and ethion on pears and grape foliage. J. Agric. Food Chem. 24, 608-611(1976).

26. Braun, H.E., Ritcey, G.M., Frank, R., Mcewen, F.L. and Ripley, B.D., Dissipation rates of insecticide in six minor vegetable crops grown on organic soil in ontario, Canada. Pestic. Sci. 11, 605-616 (1980).

27. Arora, P.K., Battu, R.S. and Singh, B., Bioefficacy of ethion against mite eutetranychus orientalis (klein) and its residues on pear fruits. pestic. Res .J. 16 (2), 33-35 (2004).

28. Jyot, G., Sahoo, S.K., Battu, R.S., Kang, B.K. and Singh, B., Dissipation of ethion on brinjal (Solanum melongena L.) under subtropical conditions at Ludhiana, Punjab, India. Bull. Environ. Contam. Toxicol. 75, 1094-1097(2005). 


\title{
التطبيق الورقى لكلوريد الكالسيوم للتقليل من متبقيات مبيد الاثيون

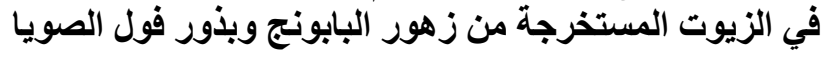

\author{
حسن عبد الجواد ، هداية كامل" و بهيرة حجازى الكياء

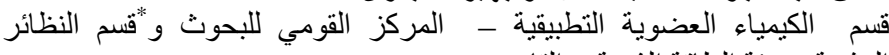

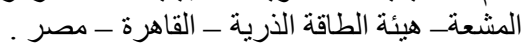

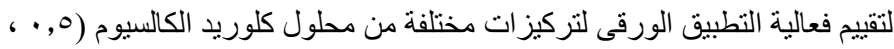

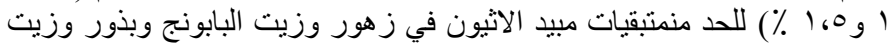

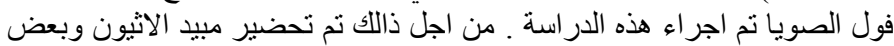

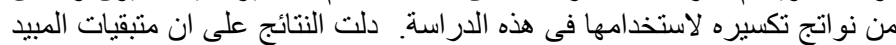

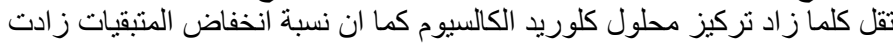

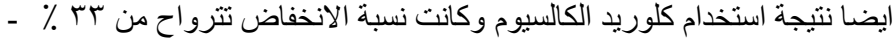

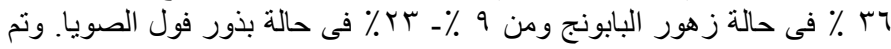

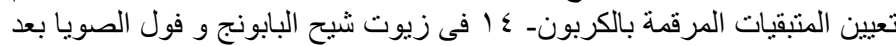

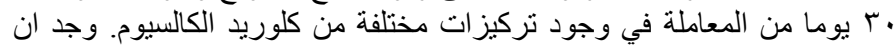

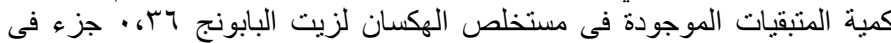

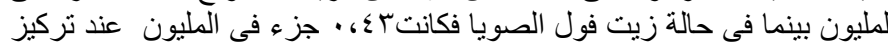

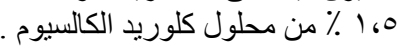

أثبت التحليل الكروماتوجر افى لمستخلص الهكسان فى الزيت الخام باستخدام

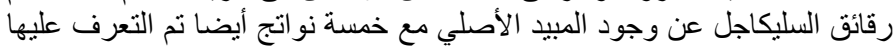
بواسطة المواد المقارنة.

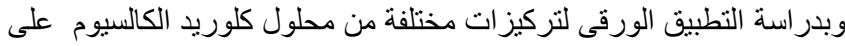

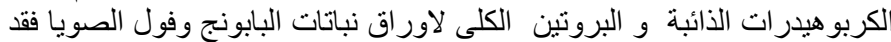

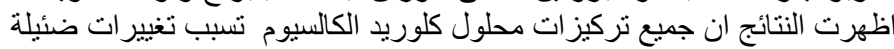

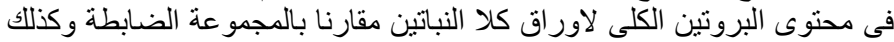

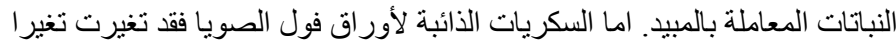

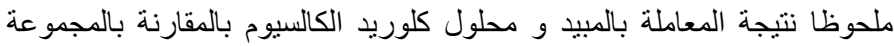

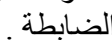

